\title{
The Democratic Republic of Congo - elections 2016. Road to democracy?
}

\begin{abstract}
It is a crucial time in African politics, as many nations in the continent will be holding elections over the next twelve months. The Democratic Republic of Congo (DRC) is also scheduled to hold a presidential election in 2016. However, the question that has left the nation in a political turmoil is whether the current President, Joseph Kabila will pave the way for a smooth democratic transition or, if he refuses to step down, will the country deteriorate into further chaos and instability? This paper looks at the current political situation in the DRC and assesses the challenges that lie on its road to democracy. In the following sections, it also analyses the role of the various actors in the current crisis including the opposition, civil society and the international community. The last section of the paper considers and lays out some possible scenarios, as the country gets ready to hold its presidential elections in November 2016.
\end{abstract}

Key words: Democratic Republic of Congo, democracy, elections 2016, Joseph Kabila, political turmoil

$\mathrm{t}$ is a crucial time in African politics as many nations in the continent will be holding

elections over the next twelve months. The Democratic Republic of Congo (DRC) is also scheduled to hold a presidential election in 2016. However, the question that has left the nation in a political turmoil is whether the current President, Joseph Kabila will pave the way for a smooth democratic transition or, if he refuses to step down, will the country deteriorate into further chaos and instability? This paper looks at the current political situation in the DRC and assesses the challenges that lie on its road to democracy. In the following sections, it also analyses the role of the various actors in the current crisis including the opposition, civil society and the international community. The last section of the paper considers and lays out some possible scenarios, as the country gets ready to hold its presidential elections in November 2016.

\section{The background to elections 2016. Democracy in the Democratic Republic of Congo}

The Democratic Republic of Congo's tryst with democracy has been a very shortlived one and, like many other nations in the African continent, it has witnessed decades of dictatorial rule with very few periods of rule by elected representatives. NzongolaNtalaja argues that in the DRC, there is a "preference for self-proclaimed rulers in place of democratically elected ones" which is "symptomatic of the history of Congo since its incorporation in the capitalist world economy in 1885" (Nzongola-Ntalaja, 2003, p. 1). 
Prior to the election of Joseph Kabila in 2006, post-colonial and independent DRC had known only two democratically elected heads of government, Patrice Emery Lumumba and Etienne Tshisekedi wa Mulumba. Unfortunately, both held effective power as Prime Minister for a very brief tenure lasting about less than three months only to be ended by a military takeover, both times by Mobutu in September 1960 and December 1992.

According to Nzongola-Ntalaja, on the one hand Mobutu's usurpation of power in 1960, 1965 and 1992 and on the other hand, Laurent Kabila's self-proclamation in 1997 negating democracy and the popular will was made possible through the external backing of the international community. He further argues that these external forces had vested interests in the Congo's enormous size, geographical location and huge amount of untapped resources, and they preferred to deal with rulers whom they hoped to influence and manipulate rather than democratically elected leaders who would be accountable to their national constituencies. It is against this backdrop that Nzongola-Ntalaja makes a valid argument stating that the struggle for democracy in Congo is "inextricably linked to the struggle for national liberation." He writes, "[i]t involves the quest for national sovereignty and genuine liberation from both colonialism and neo-colonialism in all its forms, as well as the ability of the Congolese people to freely determine their own destiny and to use their bountiful natural resources to improve their living conditions" (Nzongola-Ntalaja, 2003, p. 2). He further adds, "[m]ore importantly for the Congolese political culture, the incident revealed the elitist and undemocratic strain of bourgeois politics worldwide, as politicians prefer to solve leadership and other important issues through deal-making, rather than through open democratic processes" (Nzongola-Ntalaja, 2003, p. 189). ${ }^{1}$

The fall of Zaire's dictator, Mobutu Sese Seko only brought a series of wars that led to the deaths of millions of Congolese. It failed to bring democracy to the country. His successor, Laurent Desire Kabila suspended the constitution and ruled by decree until his assassination in 2001. His young son, Joseph Kabila who was not welcomed by the Congolese, replaced him. However, over a period of time, he gained popular support and he was expected to set the country back on course towards democratic transition (Phezo Dizolele, 2010, p. 145). It was only in 2006 that DRC witnessed its second elections after decades of authoritarian rule and it is argued that despite shortcomings in the electoral process, the complexity of the electoral laws and the intricacy of the electoral systems, the 2006 elections in the DRC were relatively peaceful (Mbata, Mangu, Budeli, 2008, p. 112).

After his win in the 2006 elections, Joseph Kabila and his advisors insisted on a constitutional revision that would extend the president's term from five to seven years, eliminate term limits, allow the president to preside over the judicial High Council and delay the decentralisation process (Phezo Dizolele, 2010, p. 148). However, the constitution of the DRC that was drafted in 2005 does not allow amendments to some important clauses.

${ }^{1}$ It refers to the incident when Mobutu appointed Tshisekedi as Prime Minister through secret negotiations in 1991, and later Jean Nguza Karl-i-Bond repeated this. Though Tshisekedi was of the view that Mobutu's departure from office was a precondition for genuine change and democratisation, he chose to accept the Prime Minister's post offered by Mobutu. 
"Article 220 of the 2005 Constitution forbids in the most unequivocal terms the revision of any constitutional clauses related to the pillars of Congolese democracy - the republican form of the state, the principle of universal suffrage, the length and limits of presidential terms, the independence of the judiciary, the representative form of government, and political and labour-union pluralism. Article 220 also forbids any constitutional revision leading to the dilution either of individual rights and liberties or of the prerogatives of the provinces and decentralized territorial entities" (Phezo Dizolele, 2010, p. 149).

\section{Joseph Kabila's stand}

Joseph Kabila took power in the Democratic Republic of Congo in the aftermath of his father Laurent Kabila's assassination in 2001. Joseph Kabila has won two elections since then and, therefore, is not eligible to stand for a third term. President Joseph Kabila's term comes to an end in 2016, and according to the constitution, he will no more be able to contest for the post of the President. The election commission of the DRC has set 27 November 2016 as the date for the presidential and legislative elections, which satisfied a key demand of the political opposition and international donors.

However, Kabila to date has not expressed his stance, which has led to speculation that he might not pave the way for a democratic transition in 2016. Kabila has remained silent and sees the elections as a 'distraction' from his political agenda, though a government spokesman announced that he would respect the constitution (Congo presidential...). In addition, the sequence of events which panned out over the last few months has made the opposition as well as the Congolese at large sceptical of Kabila's intentions. The international community too is proactively seeking to ensure that Kabila allows for a smooth transition and does not create roadblocks in the country's development.

For a very long time, since the elections of 2011, the Kabila government's attention has been to a large extent focused on strategies to amend the constitution or create legal obstacles to delay the inevitable elections of 2016. It is only in the last few months that the government has shifted its focus to the complex preparation of local, provincial, senatorial, legislative and presidential elections. The government also overtook an 'ambitious implementation of a decentralisation process' only in 2015, after stalling the process for the last two years. Though welcomed as a process that has been long overdue, the timing of its implementation has received wide criticism and is also seen as a tactic for delaying the election (Congo: Is Democratic.., p. 1).

\section{Challenges on the road to democracy Kabila himself}

Kabila, to date, has remained silent and has not made any declaration as to whether he will step down in respect of the constitutional limits (Congo-Kinshasa: Elections...). This has created frustration and speculation amongst the opposition parties, civil society and the general public. There is apprehension that the lack of commitment from Kabila 
about the end of his term could mean that he intends to stay in office indefinitely. Kabila has been criticised for employing the playing-for-time strategy called 'glissement,' which is seen as another tactic for tying up the electoral process in bureaucratic delays (DRC's Opposition Boycotts...). Be it the intention to conduct a census or the packed election calendar or the ill-timed decentralisation process, they are seen as tactics used by Kabila to extend his stay in power. Of late, the government's intolerance to external interference or criticism has been rising. The government has demanded that the UN reduce its military presence and has prevented MONUSCO from performing its mandated role of facilitating political dialogue (DRC's Opposition Boycotts...).

\section{Corruption in the government and lack of democratic institutions} The CENI

Over the years, the Commission Electorale Nationale Independante (CENI) that overlooks the conduct of elections in the DRC has been the subject of criticism. While the 2006 elections were relatively more democratic, peaceful and fair, the 2011 elections came under severe criticism for being controversial and not credible. It resulted in a longstanding crisis of the government's legitimacy. In 2011, the CENI was headed by a close confidant of Kabila, Reverend Ngoy who also came under the scanner. Criticism was also levied against the voter register, the non-transparent manner of the assembling, treatment and communication of results. Etienne Tshisekedi, Kabila's main contender contested the outcome of the election. Even when Abbot Malu Malu was appointed as the new CENI chief in 2013 by Kabila, he was disapproved of by the opposition for being too close to the President. In the last two years, on various occasions, opposition parties and civil society groups have protested against the credibility of the CENI but nothing fruitful came out of it. CENI's deliberations have been criticised for not being consensual and for its lack of dialogue with political parties and civil society (DRC's Opposition Boycotts...).

In February 2015, the CENI published the election calendar soon after the promulgation of the new electoral law. The Commission intended to complete the pending 2011 cycle by conducting local, provincial and senatorial elections in 2015 and early 2016, and also wanted to combine legislative and presidential polls on 27 November 2016. However, this calendar was not welcomed by the opposition, which criticised it for being "non-consensual, unrealistic, incoherent and unconstitutional" (DRC's Opposition Boycotts...). Opposition parties criticised it for being "not comprehensive because it's overbooked" (President Obama Urges...). Critics of Kabila see it as a ploy for him to stay in power beyond the constitutional limits (October 2015 Monthly Forecast...). The opposition has two demands: the registration of new voters since the 2011 elections and the delay of local elections until after 2016. The opposition has also expressed its concerns regarding the process of decentralisation and the impact that it would have on the electoral process.

Other issues that affect the smooth conduct of elections include the timing of local and provincial elections and the technical issues in holding them. The electoral roll, the budget, the technical feasibilities of the entire electoral calendar are some of the major 
issues. Criticism has also been levelled against the CENI's leadership and the lack of transparency (Congo: Is Democratic..., p. 18).

The resignation of the chief of the electoral commission in October 2015, Abbot Apollinaire Malu-Malu has triggered concern among the opposition that Kabila may be looking to postpone the polls scheduled for the next year. Meanwhile, Kabila has asked Congolese civil society to appoint a replacement. Human Rights Watch stated in a report that Kabila's party had employed "hired thugs" to attack opposition demonstrators in Kinshasa (DR Congo electoral commission). Three weeks later, the vice president of the CENI also resigned, which has thrown the country's political process into further turmoil (Vice president of Congo...). The vice president's resignation is widely viewed as the consequence of pressure from a government that is "seeking to undermine the supposedly independent electoral commission and render it inert" (Congo's uncertain election, 2015).

It is also argued that the elections scheduled for 2016 have exposed the loose federation of Kabila's majority government. The elections have brought to the fore internal divisions and there has also been a constant criticism that there is a lack of open dialogue within the President's Majority (MP).

\section{The electoral roll}

A major issue is the electoral roll, and the opposition was of the opinion that new voters have to be registered, because many young people have reached voting age since the completion of the last elections in 2011 . The opposition and civil society contested the constitutionality of this exclusion of new voters while the CENI opines that the local and provincial elections were part of the 2011 election cycle and therefore the electoral roll and distribution of seats must be based on the 2010-11 voter registration process. There has been no clear methodology put in place yet for updating the voter list for the 2016 elections and the possibility of including diaspora voters is also unclear (Congo: Is Democratic..., p. 19).

\section{Budget for the elections}

Another controversial issue is the budget for the elections. In 2014, the budget was estimated at $\$ 750$ million. This year it has increased to $\$ 1.145$ billion without any explanation or basis. The CENI was allocated $\$ 169$ million in 2014 but only a small amount was actually spent. The lack of guarantees on sound electoral management and uncertainty about President Kabila's intention makes donors reluctant to contribute significant amounts (Congo: Is Democratic..., p. 20).

Another attempt made by Kabila to delay the electoral process has been his refusal to disburse the necessary budgets. It has been observed that there is a constant struggle between the CENI and the government, in particular, Prime Minister Matata and VicePrime Minister Boshab, for control over the electoral process (DRC: The final countdown..., 2015). 
Meanwhile, a letter written by the CENI that was leaked says that the commission did not receive the funding as the government claimed it had, and which was supposed to be allocated for the upcoming elections. According to the CENI letter, it has received only 17 per cent of the funds allocated to it since 2013. There have also been reports of wastage and corruption within the commission, and both the budgeting and the electoral process has been anything but transparent. This has prevented the international actors from committing money for the elections (DRC Electoral Body..., 2015).

The DRC government will face yet another deficit in its budget for the elections due to the recent decision made by the Swiss trading house Glencore to halt some of its production in the DRC. The government will lose about 200 billion Congolese francs next year, which will make it harder for it to pay for the regional and national elections. This could delay the electoral process and give Kabila a reason to justify extending his stay as the president (Cost of Glencore..., 2015).

\section{Unclear roadmap and disruptions}

The ICG report states that when the Kabila government failed to amend the constitution or create legal conditions for the delay of elections, the government opted for the third option - chaos. The lengthy electoral agenda and the urgency displayed in the establishment of the new provinces caused massive confusion and disarray. The decentralisation and 'decoupage' processes are under-resourced and could create further chaos and contribute very little towards development or stabilisation (Congo: Is Democratic..., p. 17).

In June 2015, in his independence day speech, Joseph Kabila indicated the possibility of a national dialogue among the ruling majority coalition, the political opposition and the civil society to discuss issues like electoral calendar, the registration of several million voters who had become eligible since the last elections held in 2011, the financing of the electoral process and elections security. This announcement brought about mixed reactions. Some political actors feared that a national dialogue could pave the way for the modification of the constitution, including the provisions relating to the limit on the presidential term. Some warned that a dialogue would endorse a 'constitutional coup d'état.' Many political parties announced that they would not take part in the proposed dialogue as that could be used to justify the postponement of presidential elections (Report of the Secretary-General..., p. 1-2). Opposition parties have also been wary of entering into a dialogue with the President without international mediation, as they fear that the talks will lead to the formation of a national unity government that will delay the elections (DRC President Signs). Meanwhile, the Kabila government pressed for the rapid adoption of the draft law on the allocation of seats for the local elections and, subsequently, the Senate adopted the law without debate, in the absence of the opposition parties who boycotted the vote. Eventually, Kabila promulgated the law on 25 August 2015. The local elections to be held in October 2015 were hampered by the delays in adopting the outstanding legislation, the 'decoupage,' lack of consensus about the sequencing of the polls. Controversy surrounded and continued over the technical feasibility of holding local elections that were scheduled for October 2015. Several political stakeholders from 
the ruling majority as well as the political opposition called for the local elections to be postponed until after the national elections in 2016. They argued that the local elections would cause additional delays that would result from the significant financial, legal and technical requirements and would therefore impact the funding of the 2016 presidential election (Report of the Secretary-General..., p. 2). In the last week of October, a coalition spokesman said that the national census and electoral roll revision are necessary to ensure the credibility of the polls. He also added that the presidential election should be delayed by up to four years (Update 1-Congo polls...).

\section{Decentralisation process}

Twenty-one new provinces were created as part of a decentralisation process, or 'decoupage' in February 2015, a few months ahead of the scheduled elections. The administrative establishment was formally completed on 19 July 2015 and by August 2015, the 11 previous provincial assemblies were restructured into 26 and their provisional bureau was established. The 'decoupage' was delayed by almost two years and the timing is also seen as one of Kabila's tactics to delay the presidential vote and prolong his stay in power (Key DR Congo elections...). In the context of the 'decoupage' and the gubernatorial elections, tensions began to emerge. For example, in the Sankuru province, people of the Katako-Kombe territory opposed the installations of a new police sub-station, which led to the killing of a police officer and the burning down of a number of homes in the area. Though the 'decoupage' received a broad consensus because it meant decentralisation and a means of bringing the governing institutions closer to their constituencies, increasing accountability and channelling more resources to local development, it also drew criticism from various political actors as the new provinces were installed with no additional resources to support them (Report of the Secretary-General..., p. 4).

The 'decoupage' process was poorly planned and the new provinces did not have their own governors or the structures to function independently during the initial months. The main criticism levelled against the decentralisation process has been the lack of preparation and the lack of funds. The government has only remitted a small fraction of the 40 per cent of the revenue it is supposed to provide to the provinces by law (Breaking up is hard...). Another criticism levied against the decentralisation process is the timing at which it was carried out. Many believe that it the whole process was politically motivated. The former governor of the Katanga province, Moise Katumbi was once a close ally of President Kabila. However, over the last year, their relationship deteriorated and Kabila's detractors opine that the decentralisation process was carried out hastily to remove Katumbi from office, who is also allegedly a contender for next year's presidential election (Breaking up is hard...).

In September 2015, the constitutional court ruled that the local elections that were to be held the following month could not be held until governors were first elected to head the country's 21 -newly created provinces. The local elections that were scheduled to be held on 25 October 2015 could have been the country's first-ever grassroots poll. The court issued its decision, ruling that the combination of legal ambiguities in the relevant laws and the lack of funding from the government were making it impossible to organise the guber- 
natorial elections. The court also added that the government's failure to comply with the timeframe foreseen for the 'decoupage' process created a chaotic situation that threatened public security and order. And therefore, the court ordered the government to have in place transitory governing arrangements to ensure security and order in the 21 provinces.

The executive announced that it would appoint special commissioners to govern the new provinces pending the gubernatorial elections. The opposition has criticised this as unconstitutional manoeuvring by the government to delay the end of Kabila's term (Breaking up is hard...). This is despite the signing of legislation by President Kabila in August 2015 to keep the elections on a timeline as proposed by an independent commission, and he had at that time agreed to hold the first local elections on October 25. Tensions are also growing between the President and the opposition as the latter doubt the President's intention of holding timely elections.

The court ruling spurred criticisms that the Kabila government would name governors who are loyal to him and would help him stay in office. Unfortunately, Kabila did appoint temporary special commissioners to govern the 21 new provinces and several of them happen to be prominent Kabila loyalists. Each province will also be headed by two deputy commissioners to oversee economic and political matters. This move has not been well received, as it is alleged that the nominations aim to reinforce Kabila's hold on security and revenue flows in the provinces (Congo's Kabila names...).

The constitutional court also asked the electoral authorities to take a fresh look at the voting timetable and re-evaluate its calendar, citing the reason of budgetary and political constraints making it untenable. The lack of executive committees in the newly created provinces, according to the court, had also created 'anarchy' in the absence of viable local governance. Analysts argue that the 2016 election timetable could be jeopardised because of the $\$ 1.1$ billion price tag and the difficulties in establishing the 21 new provinces (DRC Court Orders...).

A possible negative fallout of the decentralisation process that has been implemented amidst political uncertainty is the likelihood of ethnic tensions being fuelled by political battles. For instance, the new province of Lualaba that was created from the breakup of Katanga is now Congo's biggest source of copper and, as a result, the mines have attracted job seekers from across the country. There is a possibility that the ethnic communities that dominate the region, including the Yeke, Ndembo, Sanga and Lunda, may target some of the job seekers. There is also a proxy battle that is under way for the control of Lualaba between Kabila and Katumbi, which threatens to trigger not only political tensions but also ethnic frictions and, as a consequence, mining companies may get caught in the political crossfire (Congo's Opposition Coalescing...).

\section{Other players Opposition parties}

The political landscape is fragmented and there are only a few large majority opposition parties and many small ne-man parties which often have a strong regional or ethnic affiliation. In March 2015, around 477 political parties were registered with the interior ministry (Congo: Is Democratic..., p. 10). 
The government's delay in holding timely elections united the parliamentary opposition under an umbrella group known as 'Dynamique pour l'unite d'actions de l'opposition', or Dynamic for Unified Action by the Opposition (DRC's Opposition Boycotts Senate...). However the International Crisis Group (ICG) report argues that the opposition is also as disorganised as the ruling government is, and that the opposition is centred on four major parties. The most important party is the Union for Democracy and Social Progress (UDPS), which is led by former Mobutu opponent, Etienne Tshisekedi with its major base in Kinshasa and Kasai provinces. But over the years, it has weakened over issues of succession for the ailing Tshisekedi and the party's post2011 election strategy. The second party is the Union for the Congolese Nation (UNC) led by former Kabila ally Vital Kamerhe from South Kivu. Though Kamerhe's political past still haunts him, the weaknesses of the UDPS increase the UNC's political weight. The other main opposition party is the Movement for the Liberation of Congo (MLC). However, the image of the party is tarnished by the incarceration and pending trial of its leader Jean-Pierre Bemba by the International Criminal Court. The capacity and loyalty of the party members is also limited by the judicial case against their leader. The fourth party is the Republican Opposition under Senate President, Kengo Wa Dondo (Congo: Is Democratic..., p. 14). There are other prominent individuals who are part of the opposition, Martin Fayulu and Clement Kanku and smaller parties that lack a large political base. Religion in DRC is a crucial organisational element, and the churches' role in the electoral process will be as important as the political parties. According to analysts, the most influential bloc in the opposition is the Catholic Church, led by Cardinal Laurent Monsengwo. It is argued that the question of constitutional reform brought some unity to the otherwise scattered opposition. Opposition parties, civil society organisations and the Catholic Church mobilised against the reforms. The UNC and the UDPS have taken the lead and organised rallies and marches since August 2014. Their demands have been: opposition to constitutional reform, the opening of an inclusive political dialogue facilitated by the UN, the release of political prisoners and the publication of a comprehensive electoral calendar. It is also argued that though the opposition parties have common objectives, they remain divided over strategy and also suspect each other's personal ambitions (Congo: Is Democratic..., p. 14).

\section{G7}

On 16 September 2015, Kabila expelled seven senior political members from the ruling coalition as a reaction to a letter written to him asking him to step down as President in 2016 (Congo-Kinshasa: Elections...). The group of seven political parties known as the 'G7' had written to President Kabila warning him of the risk of destabilisation of the country if the constitution was violated, and called for local elections to be held after the national and provincial elections. Kabila was unimpressed by the letter and expelled the seven parties from the coalition. The group finds its origin in the dissidence of Pierre Lumbi who was later joined by six other disillusioned members, Olivier Kamitatu, Jose Endundu, Christophe Lutundula, Charles Mwando-Simba, Kyungu wa Kumanza and Dany Banza. For Kabila, the G7 was too big to be ignored, yet too small to make a differ- 
ence. The G7 have 79 seats in the parliament, while the majority holds 353 seats including the 79 seats. Earlier in March 2015, the G7 had addressed a letter to the President, in which they strongly criticised the majority's position and warned of a political crisis. It, in turn, called for cohesion and regular and open dialogue for the majority to win the elections (Congo: Is Democratic..., p. 12).

\section{Moise Katumbi}

One of the likely presidential candidates for the 2016 elections is Moise Katumbi, the 50 -year old former governor from the copper-rich Katanga province in the southeast of DRC. Katumbi has made millions through mining and other business interests and Kabila made him governor of Katanga in 2006. However, their relationship became strained when Katumbi used a public rally in December 2014 to urge his supporters to challenge Kabila's third term as president. Owing to his large support base in Katanga and the vast amounts of money at his disposal, some analysts view him as the most credible successor to Kabila. Though he has been criticised for lacking long-term vision and using the office to advance his own business interests, Katumbi has been credited as Katanga's governor with restoring infrastructure and supporting the booming mining sector. Katumbi has also been active in lobbying in the US for its support in conducting timely elections (Millionaire governor gears...). Some of the top Washington lobbyists are helping him to push for a timely and orderly vote in November 2016. If Katumbi makes a formal bid and manages to get the declared support from some of Kabila's partners, then analysts observe that it could be serious enough to force Kabila into the open. Katumbi has also received the backing of the 'G7,' the group that formed to express their criticism of Kabila's refusal to publicly declare his intentions. According to a report, Moise Katumbi's position within and outside the majority is likely to be the 'game changer,' both for the president and the opposition leaders (Congo: Is Democratic..., p. 13).

Katumbi is one amongst many contenders for the post of president. Veteran politician Leon Kengo and relative newcomer Bernard Katompa are also eyeing the post. Katompa is a businessman who ran Standard Bank's Liberty Africa insurance and wealth management service, and has acknowledged the need for economic reforms in the country. He has also promised to work with the World Bank to transform Congo's business environment to one of the best in Africa (Congo's future hinges ...).

\section{People's protests and government's reaction}

The UN Special Representative of the Secretary-General for the DRC noted that the electoral process marked the political situation in the country and political tensions were "running high" ahead of the 2016 presidential and legislative polls (DR Congo: political tensions...). The tense political climate in Congo is characterised by public protests, accusations and counter-accusations and the intervention of the international community.

In 2014, in order to obstruct opposition rallies, the national and provincial governments took administrative measures. Opposition leaders were harassed or arrested during 
protests and several of them are facing legal proceedings. The government also targeted civil society movements such as Filimbi in Kinshasa and LUCHA in Goma that mostly comprise students and young professionals who are active on social media and are in contact with similar movements in countries like Senegal and Burkina Faso.

In January 2015, violent protests erupted against the government owing to fears that the Kabila government was trying to delay the elections through the conduct of a census. Protestors wanted to halt parliamentary proceedings to adopt a new electoral law that would make it mandatory to hold a national census before the elections. The January street protests were also fuelled by government spokesperson Lambert Mende's declaration of the possibility of the elections being postponed until 2017 (Congo: Is Democratic..., p. 11). At least 42 people died in the protests in Kinshasa and other cities. The opposition said that the plan would amount to a 'constitutional coup' by Kabila, as the census would have taken up to three years to be conducted in a country as big as Western Europe, and thus would have delayed the elections. The government had argued that the census was vital to ensure that polls are free and fair, as the country had not witnessed a reliable census since its independence in 1960. However, following the protests, the government denied the claims and Kabila thereafter dropped plans of carrying out the census before the elections (DR Congo sets election...).

The DRC government also imposed an Internet blackout in the country to suppress protests against Kabila. The government ordered telecommunications companies to sever all Internet and short-message services, following anti-government protests that spread from the capital to the eastern Kivu provinces. Analysts warned that the oppression brings a risk of the country being plunged into even deeper turmoil, and that it could "unleash unpredictable political and social forces" and "the country is ill-prepared to manage these peacefully." It is argued that the government's repression and response to the unrest by shutting down access to the Internet reflects its growing unease over the political situation (Democratic Republic of Congo Extends...).

In September 2015, the opposition called for the implementation of the constitution and the recommendations of the 2002 inter-Congolese dialogue conference. Opposition leaders also organised rallies to stress their opposition to any constitutional change that would enable Kabila to stand for a third term. There is a lack of unity even amongst the ruling coalition of parties (Congo-Kinshasa: Elections...).

The UN notes that since the beginning of 2015, over 123 human rights violations have been documented in the context of the electoral process, mainly registered in the provinces of North Kivu, South Kivu, Kinshasa and the former province of Kasai Oriental (Report of the Secretary-General..., p. 15).

\section{Role of international actors}

The international community has been concerned about the deteriorating human rights situation and killings in the DRC prior to the elections. There is apprehension that this could negatively impact the credibility of elections (Congo-Kinshasa: Elections...) International actors, as well as the UN are also apprehensive about the electoral calendar. The past experience with the elections of 2011, the slow pace of preparations for 
the current elections, as well as the lack of transparency by the CENI induce very little confidence among international actors (Report of the Secretary-General..., p. 15). In addition, the legal manoeuvring and the recently accelerated decentralisation process are making not only the international community, but also the opposition and civil society wary of Kabila's intentions (Report of the Secretary-General..., p. 15). Without a clear commitment from the Congolese government, international actors are not enthusiastic about financially supporting the country's electoral process. There is also apprehension that the constitution would be disregarded, which would push the country into further chaos (DRC: The final countdown).

The United Nations is concerned about the political situation in the DRC. The Secretary-General's report of September 2015 called for the peaceful, timely and credible conduct of elections in November 2016. The Special Representative of the SecretaryGeneral stated that if the country manages to hold timely elections then it "would send a clear message to the world that the Democratic Republic of Congo is a nation that respects its Constitution, a nation keen on a peaceful transition of power, a nation that will consolidate peace" (DR Congo: political tensions...).

Within the UN Security Council, there is division among the P5 on constitutional and electoral matters and their views on the issue of sovereignty. Countries like Russia and China see it as an internal, domestic matter, while the western countries are of the opinion that a strong message should be sent to individuals who try to extend their stay in power beyond their constitutional mandate. However, in the case of the DRC, unlike Burundi, there is no constitutional ambiguity regarding Kabila's end of term, and therefore unity and consensus among the Council members, especially the P5, is expected (October 2015 Monthly Forecast...).

In the context of the electoral process, the UN peacekeeping mission in the DRC, MONUSCO, intensified contacts with a range of political actors across the political spectrum and with civil society. The mission also provided assistance to the national independent electoral commission with limited technical assistance, while the provision of strengthened technical assistance was pending from other UN entities and international partners (Report of the Secretary-General..., p. 11).

The European Union is wary of the entire electoral process, which is partially because of the criticism of the 2011 elections by the EU Court of Auditors following funding. The EU and others, such as Belgium, have some funding left for the 2011 cycle, but thus far have not made any commitments. The US has earmarked \$20 million mostly for civil society and voter education. It also has been proactive in pushing for timely elections in Congo by holding talks with President Kabila and urging his government to make way for democratic transition. The UN Development Programme-led support project for the 2015-17 elections foresees a total support package of \$123 million, a significant part of which has been allocated for the voter roll (Report of the Secretary-General..., p. 21).

\section{Possible outcomes}

The likely scenarios in which events may pan out over the next twelve months can be assessed as follows. Scenario A could be where President Kabila steps down and 
elections are carried out in a peaceful manner. There is a change of government through democratic means, and thereby Kabila would become the first Congolese president to step down peacefully from power. If Kabila does peacefully step down, it would be the first peaceful, executive handover of power since the DRC's independence, which would eventually consolidate democratic institutions in the Congo.

In scenario B, Kabila steps down but does not pave way for a democratic transition. Instead, there is a leadership switch within the majority, which is referred to as the Putin-Medvedev scenario (Report of the Secretary-General..., p. 10). ${ }^{2}$ However, there is speculation that he might want to retain power within the family, and might choose his twin sister Jaynet as his successor (DRC: The final countdown...). There is also a probability of him using immoral means of bribing the opposition parties to extend his stay in power.

In scenario C, which is the worst-case scenario, Kabila refuses to step down, removes or amends the constitutional clause on the two-term limit and the election process is delayed indefinitely. In such a case, the internal security of the DRC would collapse, leading to urban political unrest and protests. There would be an erosion of democratic institutions, and analysts also predict a rift within the military guard and the presidential guard. This is because Kabila does not have the strong team around him that he had in his early years of presidency and, of late, he has tended to meet with key leaders individually, which has led to the disappearance of a holistic approach. This has created a lot of bitterness, frustration and insecurity among the members of the majority $(D R C$ : The final countdown...).

Kabila could resort to brutal repression of these protests. Such a situation could be a nightmare for the DRC because of the violence that would ensue. The international community could be forced to step in, and the DRC might be pushed into further chaos. There is also a fear that neighbouring countries like Burundi, Rwanda and Uganda would take advantage of the instability within the DRC to gain security and financial incentives, which could threaten a return to regional instability (An Election Crisis in...).

\section{Will the other African countries set a precedent?}

As stated at the beginning of the paper, other African nations, too, will be holding elections over the next twelve months and, like the DRC, these nations are also standing at the threshold of building stronger democratic institutions within their territories. While some of these nations have witnessed peaceful elections and smooth democratic transitions, others have had a more turbulent political process. There is a valid fear amongst the Congolese that Kabila could take a leaf out of the latter examples and follow suit. For example, in Burundi, Pierre Nkurunziza side-stepped the constitutional limits and evaded the law. He is accused of pressurising the judiciary to vote in his favour to enable him to stand for a third-term and holds the post "behind a façade of judicial approval." Nkurunziza also managed to buy off some of the opposition parties and split them politically (An Election Crisis in...).

${ }^{2}$ A Putin-Medvedev scenario implies where Kabila's confidant becomes the President and Kabila the Prime Minister for one term, after which Kabila would return to power as President. 
On the other hand, countries like Nigeria and Tanzania witnessed smooth, democratic transitions, which are good examples that President Kabila could emulate. Nigeria's former President Jonathan Goodluck accepted defeat in the elections and paved way for Muhammadu Buhari to take over. Recently, Tanzania too saw a peaceful transition of power from former President Jayaka Kikwete (who held two terms in office) to the current President, John Magufuli.

\section{Conclusion}

Given Kabila's silence about the future and the tactics adopted to delay the elections, there is a general apprehension and anxiety about what the future holds for the country. However, it is necessary to point out that the elections are not the only prerequisite to making the DRC democratic. The following lines succinctly sum up the essence of Congo's journey towards becoming a democratic country.

“...elections alone do not guarantee the establishment of a true democracy but are essential to it, since no regime would qualify as democratic in our modern era if it does not hold regular elections" (Mbata, Mangu, Budeli, 2008, p. 109).

It is definitely not going to be an easy journey that the DRC will have to undertake. There are numerous challenges. Internally, there is a dearth of democratic institutions and parameters such as the rule of law, a legitimate constitution, an autonomous and impartial electoral commission, an independent judiciary, the lack of a non-partisan army, police force and security service, the absence of a vibrant civil society or a democratic culture among the people and, above all, a leadership deficit and the lack of an effective leader who is committed to democratic change, national reconciliation and nation-building. These were some of the challenges that were observed after the elections of 2006 (Mbata, Mangu, Budeli, 2008, p. 112-113). Unfortunately, almost ten years later, most of these factors continue to challenge and impair the country's transition to democracy.

The time is ripe for the international community to engage Kabila constructively and pressurise him to step down as President. International actors like the US and the EU also intend to slap economic sanctions against Kabila and his family if he refuses to end his tenure the next year. Lack of external funds could also stifle the country's economy. Some analysts also opine that granting legal impunity to Kabila after the end of his term could convince him to pave way for a smooth democratic transition (Can Joseph Kabila...). It is in the best interests of Kabila to respect the constitution and gracefully step down as president. In the current situation, there are far more negative consequences and drawbacks than advantages for Kabila if he refuses to give up his post. Otherwise, he may be subject to the same fate that his father was, years ago.

\section{Bibliography}

An Election Crisis in Democratic Republic of Congo Could Mean War, 16.08.2015, "Geopolitical Monitor", http://www.geopoliticalmonitor.com/an-election-crisis-in-democratic-republic-of-congocould-mean-war/, 14.10.2015. 
Breaking up is hard to do: the DRC's risky decentralization drive, 07.10.2015, "The National Law Review", http://www.natlawreview.com/article/breaking-hard-to-do-drc-s-risky-decentralizationdrive\#sthash.vw6RYbxN.dpuf, 13.10.2015.

Can Joseph Kabila cling to power?, 15.09.2015, "Inside Story, Aljazeera”, http://www.aljazeera. com/programmes/insidestory/2015/09/joseph-kabila-cling-power-150915165952882.html, 16.10.2015.

Congo: Is Democratic Change Possible?, Africa Report No. 225, "International Crisis Group Report", Brussels, 05.05.2015.

Congo-Kinshasa: Elections fever grips DRC stakeholders, 21.09.2015, “Allafrica.com”, http://allafrica.com/stories/201509211333.html, 16.10.2015.

Congo presidential election set for November 27, 2016: commission, 12.02.2015, "Reuters", http:// www.reuters.com/article/2015/02/12/us-congodemocratic-election-idUSKBN0LG28M201502 12\#OaXMTAgqL4A7yRgG.97, 15.10.2015.

Congo's future hinges on policy and law, 06.11.2015, "Business Day Live”, http://www.bdlive.co.za/ opinion/2015/11/06/congos-future-hinges-on-policy-and-law>, 12.11.2015.

Congo's Kabila names provincial commissioners as elections lag, 29.10.2015, "Reuters", http://uk.reuters.com/article/2015/10/29/uk-congodemocratic-politics-idUKKCNOSN2VM20151029, 09.11.2015.

Congo's Opposition Coalescing to Stop Kabila from Extending Rule, 06.10.2015, "Bloomberg Business", http://www.bloomberg.com/news/articles/2015-10-06/congo-s-opposition-coalescingto-stop-kabila-from-extending-rule, 24.10.2015.

Congo 's uncertain election, 06.11.2015, “Open Democracy”, https://www.opendemocracy.net/williamclowes/congo-s-uncertain-election, 02.11.2015.

Cost of Glencore unit's suspension will complicate Congo's elections, 26.10.2015, "Reuters", http:// uk.reuters.com/article/2015/10/26/uk-congodemocratic-economy-glencore-idUKKCN0SK22I20151026, 03.11.2015.

Democratic Republic of Congo Extends Internet Blockage, 22.01.2015, "The Wall Street Journal", http://www.wsj.com/articles/congo-blocks-internet-access-amid-protests-against-presidentkabila-1421938042, 30.10.2015.

DR Congo electoral commission chief's resignation sparks concern, 10.10. 2015, "Yahoo news", http://news.yahoo.com/dr-congo-electoral-commission-chiefs-resignation-sparks-concern-215037743.html, 02.11.2015.

DR Congo: political tensions 'running high' ahead of 2016 elections, UN officials warn, 07.10.2015, "UN News Centre", http://www.un.org/apps/news/story.asp?NewsID=52191\#.VhaEPUIRrqQ, 15.10.2015.

DR Congo sets election date after protests, 1.02.2015, "BBC News", http://www.bbc.com/news/worldafrica-31448143, 14.10.2015.

DRC Electoral Body Pleads Lack of Funds, 13.10.2015, "Voice of America", http://www.voanews. $\mathrm{com} /$ content/democratic-republic-congo-electoral-body-pleads-lack-funds/3004596.html, 16.10.2015.

DRC Court Orders Review of Election Schedule, 08.09.2015, "Voice of America", http://www. voanews.com/content/democratic-republic-congo-orders-review-election-schedule/2952811. html, 11.10.2015.

DRC's Opposition Boycotts Senate, Dismisses Kabila's Ploy to Stay in Power, 11.08.2015, "RFI English", http://www.english.rfi.fr/africa/20150810-opposition-Democratic-Republic-CongoDRC-boycott-senate-dismisses-kabila-ploy-stay-p, 13.10.2015.

DRC President Signs Legislation on Local Elections, 26.08.2015, "Voice of America", http://www. voanews.com/content/democratic-republic-congo-president-signs-legislation-local-elections/2934236.html, 27.10.2015. 
DRC'S Opposition Boycotts Senate, Dismisses Kabila's Ploy to Stay in Power, 11.08.2015, "RFI English”, http://www.english.rfi.fr/africa/20150810-opposition-Democratic-Republic-CongoDRC-boycott-senate-dismisses-kabila-ploy-stay-p, 16.10.2015.

DRC: The final countdown to the 2016 elections or just another transition?, 09.10.2015, "African Arguments", http://africanarguments.org/2015/10/09/drc-the-final-countdown-to-the-2016elections-or-just-another-transition, 13.10.2015.

Key DR Congo elections set to be delayed after court ruling, 08.09.2015, "Yahoo News", http://news. yahoo.com/key-dr-congo-elections-set-delayed-court-ruling-173729149.html, 22.10.2015.

Mbata B., Mangu A., Budeli M. (2008), Democracy and elections in Africa in the Democratic Republic of Congo: Lessons for Africa, "Law, Democracy and Development", vol. 12, no. 1, p. 112.

Millionaire governor gears up for 2016 Congo election bid, 11.08.2015, "Reuters", http://uk.reuters.com/ article/2015/08/11/uk-congodemocratic-politics-idUKKCN0QG1E020150811, 13.10.2015.

Nzongola-Ntalaja G. (2003), The Congo From Leopold to Kabila A People's History, Zed Books, New York.

October 2015 Monthly Forecast, Democratic Republic of Congo, 01.10.2015, "Security Council Report", http://www.securitycouncilreport.org/monthly-forecast/2015-10/democratic_republic_ of the_congo_9.php, 16.10.2015.

Phezo Dizolele M. (2010), The Mirage of Democracy in the DRC, "Journal of Democracy", vol. 21, no. 3 .

President Obama Urges Peaceful DRC Elections, 06.04.2015, "Voice of America", http://www. voanews.com/content/president-obama-urges-peaceful-drc-elections-that-respect-the-constitution/2708085.html, 15.10.2015.

Report of the Secretary-General on the United Nations Organization Stabilization Mission in the Democratic Republic of the Congo, "United Nations Security Council", S/2015/741, 28.09.2015.

Update 1-Congo polls must be delayed 2-4 years - ruling coalition spokesman, 31.10.2015, "Reuters", http://af.reuters.com/article/drcNews/idAFL8N12V0P420151031, 04.11.2015.

Vice president of Congo elections commission resigns, 31.10.2015, "Reuters", http://www.reuters.com/ article/2015/10/31/us-congodemocratic-politics-idUSKCNOSP0KZ20151031, 05.11.2015.

\section{Demokratyczna Republika Konga - wybory 2016. Droga do demokracji?}

\section{Streszczenie}

Afrykańska polityka znajduje się obecnie w punkcie zwrotnym, stojąc u progu wyborów, jakie w ciagu następnych dwunastu miesięcy zostaną przeprowadzone w wielu krajach tego kontynentu. Również w Demokratycznej Republice Konga (DRK) zaplanowano wybory prezydenckie w 2016 roku. Kraj popadł jednak w polityczny zamęt wobec pytania czy obecny prezydent, Joseph Kabila utoruje drogę pokojowej zmianie demokratycznej, czy też kraj stoczy się w pogłębiający się chaos i destabilizację, jeśli odmówi ustąpienia z urzędu. Artykuł przedstawia aktualną sytuację polityczną w DRK i ocenia wyzwania, wobec jakich kraj stoi na drodze do demokracji. Jego dalsza część poświęcona jest analizie ról, jakie w obecnym kryzysie odgrywają rozmaici aktorzy, tacy jak opozycja, społeczeństwo obywatelskie i społeczność międzynarodowa. Ostatnia część artykułu omawia możliwe scenariusze wydarzeń w czasie przygotowań kraju do wyborów prezydenckich w listopadzie 2016 roku.

Słowa kluczowe: Demokratyczna Republika Konga, demokracja, wybory 2016, Joseph Kabila, zamęt polityczny 